\title{
ANALYSIS OF PARKING MANAGEMENT POLICY IN GARUT REGENCY
}

\author{
Ikeu Kania \\ Universitas Garut \\ Email: ikeukania@fisip.uniga.ac.id
}

\begin{abstract}
Parking is an inseparable component or aspect of the need for a transportation system because every trip with a private vehicle generally always starts and ends in the parking lot. Regarding parking management in this study, namely analyzing how the Garut Regency Transportation Service carries out parking management in Garut Regency in its implementation, the inhibiting factors that affect parking management, and how the efforts are made to overcome the parking management problem in the Regency arrowroot. The method used by the researcher is a qualitative descriptive method that describes parking management with data collection techniques that include observation, interviews and documentation. The results of this study in parking management are analyzed with management functions, namely planning, organizing, mobilizing and monitoring where there are still many things that need to be improved again because there are so many obstacles and problems in conducting the parking management analysis, which is caused by factors that hinder into the parking lot. Parking management is factors of awareness, communication and coordination, and resource factors carried out by employees and parking attendants involved in managing the parking lot.
\end{abstract}

Keywords: Management, Parking, Transportation, Department of Transportation.

\section{A. INTRODUCTION}

In many areas of life, times have progressed rapidly. The need for transportation is one area of life affected by the changing times (Wahyusetyawati, 2017). Motorcycles or cars are now owned by almost everyone from all walks of life. With the exponential increase in the number of vehicles, the business of parking in public places is mushrooming as vehicle owners desperately need a parking space. With this service, individuals who are often in public places can park their vehicles safely and comfortably. Moreover, the parking business is also a profitable and lucrative business for everyone because managing parking makes a lot of money (Taruno, 2017).

A lot is going on in the city centre, which has an impact on traffic. Activity centres may include commercial and academic buildings, industrial areas, and entertainment venues, among other types of facilities. The use of private cars continues to increase along with transportation needs in modern times like today (Kesek, 2013). Consumers prefer to buy things they don't need just because they're attractive, regardless of whether they need them or not. Parking lots will be more desirable as the number of cars increases. Therefore an effective parking design is fundamental to be appropriately used while still allowing parking positions (Hidayat et al., 2018). Parking is a part of our everyday life, and we are used to seeing it. Every day, we see people park on the street arbitrarily, which annoys other road users, pedestrians, and those operating cars.

There are many factors to consider when it comes to parking, such as parking space, parking fees, convenience, and parking services in between. While most people want to park 
their car near their destination, in a busy (public) area with high parking demand, this can cause significant problems (Riyanda \& Dompak, 2017). When compared to the number of motorized cars in the parking lot, the parking lot's capacity is not balanced. In addition, a large amount of open land has been converted into high-rise buildings and houses, resulting in a scarcity of parking spaces (Soesilowati, 2008).

It is legally prohibited to park in the middle of the highway, but parking on the side of the road is generally allowed. Parking facilities are built with most buildings to facilitate vehicles using the structure (Puspitasari \& Mudana, 2017). Included in the definition of parking are any car that stops at certain places, whether or not indicated by traffic signs, and not solely to raise and lower people and goods. There are three main types of parking based on the arrangement of the vehicle's position, namely parallel parking, perpendicular parking, and oblique parking (Maulidya et al., 2021).

As part of the community and as road users, it is undeniable that almost all of our activities outside the home are related to the road as a means of connecting from one place to another. and Connecting facilities such as motorized vehicle transportation are not far from the parking lot (Paisal, 2014). A place where transport stops for a while. However, parking must also be in a particular area, according to applicable traffic laws. Please note that there are two categories of parking, namely official parking and unofficial parking; official parking is managed by the Department of Transportation, while unofficial parking is managed by someone who does not have an official permit from the Department of Transportation (Suthanaya, 2010). Parking attendants also know parking which is obtained from training held by the Department of Transportation. Before officially becoming a parking attendant and their experience as a parking attendant. On duty, parking attendants also have principles, techniques in carrying out their duties.

In Garut Regency, parking seems to be increasingly violating the rules, and it is difficult to discipline and reprimanded by the authorities. The parking area in Garut Regency requires a lot of arrangement because the parking area is very narrow, and many even eat the road, which causes congestion around the highway, especially on Street of Ahmad Yani. Apart from the parking lot that needs to be neatly reorganized, what must be analyzed is the management of the next parking lot, namely the parking attendants who often violate the rules that have been set, namely the many parking attendants who charge arbitrary rates, do not wear their official clothes. Many parking attendants do parking by lending their official clothes to others without a decision letter from the Department of Transportation in doing the parking.

\section{B. LITERATURE REVIEW}

\section{Public Administration}

Public Administration is a "species" within the scope of the "genus" of administration (Administration) which means a cooperative human activity. We can identify other species such as commercial or corporate administration (business administration) and private noncommercial administration. As with the term administration, the term State Administration also has various definitions. However, if we examine more deeply the definitions of State Administration, we can see from two different thinking patterns.

Robert V Presthus (1959) explained the meaning of State Administration with the following expressions: (1) "public administration involves the implementation of the public 
which representative political virtues have determined". (State Administration includes the implementation of government policies that political representative bodies have established); (2) "public administration may be defined as the coordination of individual and group efforts to carry out public policy. It is mainly occupied with the daily work of government". (Administration can be defined as the coordination of individual and group efforts to implement government policies. This is the government's daily work), and (3) "in sum, public administration is a process concerned with carrying out public policies, encompassing innumerable skills and technologies which give order and purpose to the efforts of large numbers of people. And the intent of the actions of large numbers of people).

\section{Management}

The word "management" can be equated with management, which also means regulation or management (Arikunto, 2005). Many people define management as setting, managing, and administering, and that's the definition that's popular today. Management is defined as a series of work or efforts carried out by a group of people to carry out a series of work in achieving specific goals. Griffin (2004) defines management as follows: "Management is the process of planning and decision making, organizing, leading and controlling and organization human, financial, physical and information resources to archive organizational goals efficiently and effectively."

It is said that management is a process of planning and decision making, organizing, leading and controlling the organization's human, financial, physical and information resources to achieve organizational goals efficiently and effectively. Nanang Fattah (2004) argues that the management process involves the main functions performed by a manager or leader, namely planning, organizing, leading, and controlling. Therefore, management is defined as planning, organizing, teaching, and managing the organization's efforts with all its aspects to achieve organizational goals effectively and efficiently.

Management in English is known as manage, which means collecting, organizing, implementing, and managing (John M. Echols \& Hasan Shadily) (Badrudin, 2013). Meanwhile, in the Indonesian dictionary (W. J. S Poerwadaminta) (Badrudin, 2013), management is defined as managing a large company. Management or arrangement is carried out by a manager (regulator/leader) based on the order of the management. Management is a scientific discipline tasked with finding the truth in the predicate of theoretical and methodological dimensions that must be tested and proven objectively based on facts/data.

\section{Parking}

Decree of the Director-General of Land Transportation No. 272 CHAPTER I concerning technical guidelines for operating parking facilities, namely parking is a temporary immobile state of a vehicle. Implementing a transportation system can not be separated from the problems that occur, among others, parking management. One of them is providing an ideal parking area for vehicles, especially vehicles parked in places with many visitors, such as markets. This can also reduce the number of cars that use the road for parking to prevent congestion in the traffic flow in Garut Regency. 


\section{METHOD}

The research method used in this study is qualitative. Sugiyono (2016) defines qualitative methodology as a research procedure that produces descriptive data in written or spoken words from people and observable behaviour. Sugiyono (2016) states that there is no other choice in qualitative research than to make humans as definite forms, namely humans as subjects and objects in study or as sources and diggers of information. Problems, research focus, research procedures, hypotheses used, even the expected results, all of which cannot be determined with certainty and beforehand. Descriptive data obtained in this study are descriptive data about parking management analysis in Garut Regency.

\section{RESULT AND DISCUSSION}

In the management of parking in Garut Regency, which is carried out by the Department of Transportation, UPTD Parking, Garut Regency, which consistently implements management functions in the implementation of parking management so that in its performance it always refers to efforts to achieve the expected goals. In parking management in Garut Regency, there are still some obstacles in parking management problems according to its function. However, in reality, these functions have not all run optimally; there are still many shortcomings ranging from planning, organizing, mobilizing to monitoring which is still not maximally carried out by both the service and its parking attendants who violate the regulations.

Following the main tasks and functions of the UPTD parking manager of the Garut Regency Transportation Service, the main objectives of the parking management policy are as follows;

1. To control the number of vehicles entering an area,

2. Increase local revenue collected through parking fees,

3. Improve the function of the road so that it is following its role,

4. Improve the smoothness and safety of traffic,

5. Supports other traffic restriction measures.

Based on this orientation, the mechanism and process of parking management in Garut Regency by the UPTD Parking manager of the Department of Transportation can collaborate in several stages as follows:

\section{Parking Management Planning}

Planning is the process of setting goals and deciding how a policy or program can be achieved. Parking management planning is a parking management plan where the parking planning is prepared based on the facts faced to make pictures or formulations of activities in the future to achieve the desired results. So that in preparing parking management planning, it is necessary to have aspects that support and form of cooperation with third parties so that the implementation of government policies can be carried out correctly. Street of Ahmad Yani is one of the roads that is often faced with traffic problems that are not smooth due to parking that is not well organized. One of the causes of congestion that occurs on Street of Ahmad Yani is because of the wrong vehicle parking procedures and patterns that do not follow the applicable system and regulations from the Transportation Service carried out by illegal parking interpreters as well as vehicle parking activities that carry out loading and unloading and 
parking. Public vehicles in the middle of public roads to drop off and pick up passengers. There are still many parking lots that have not been overlooked by the Department of Transportation, which are potential points of acceptance. In determining the possible effectiveness of Ahmad Yani's public roadside parking in several shops and markets, it must be following the laws and regulations, where the determination of the location and construction of the parking facilities must pay attention to:

a. General layout plan

b. Traffic impact analysis, and

c. Convenience for road users.

\section{Parking Management Organizing}

Organizing parking management on the edge of Ahmad Yani's public roads, which in this stage describes the UPTD process for the Garut Regency Transportation Office parking manager in dividing tasks/work so that everyone knows what their position is their duties are, what their obligations are. This is important so that implementers can know clearly about the objectives to be achieved in implementing policy implementation and know clearly and firmly what they should do. Provisions or rules for implementing a policy must be conveyed to the right person, clearly accurate, and consistent with specific requirements or regulations. If not, there will be a misunderstanding between implementers in implementing a policy so that the results will not follow what is expected. The confusion of the implementers will provide an excellent opportunity to enforce policies that are not following the desired provisions. Likewise, policymakers must communicate with policy implementers in mandating policies to implementers, not only through instructions or orders.

In general, the division of labour in the organizational structure of the UPTD Parking Manager of the Garut Regency Transportation Service is divided into two aspects of activity as follows:

a. Administrative aspects, which take care of non-technical parking matters, such as personnel, finance, and general affairs, are managed by the administrative sub-section.

b. Operational, technical aspects, which take care of parking technical matters, such as planning, operation, and maintenance, are managed by functional groups.

\section{Parking Management Movement}

Actuating is an action to ensure that all group members strive to achieve goals following managerial planning and organizational efforts. So mobilization moves people to work independently or consciously together to achieve the desired goals effectively. In the organization, mobilization is the most essential and dominant function in the management process because humans are the direct driving function. Many terms are used for this one management function. In carrying out parking, both drivers and parking attendants must pay attention to the parking limit stated by road markings, vehicle safety by locking the vehicle door and installing the parking brake.

\section{Parking Management Supervision}

Control is a process of determining what is being achieved, namely standards, what is being done, namely implementation, assessing implementation, and making improvements so 
that performance is following the plan, that is, aligned and standard. According to Husaini Usman (2006), states control includes monitoring, assessment and reporting. Monitoring and evaluation are often called monev, which stands for monitoring and evaluation. In parking, supervision carried out by the UPTD parking of the Transportation Service that each member of personnel will distribute an official ticket to the parking attendant and withdraw the retribution from the parking attendant according to the amount that has been determined by the parking UPTD of the Transportation Service and become a monitor in overseeing traffic conditions and conditions. parking along Street of Ahmad Yani. From the definition above, the writer can conclude that the control is carried out before the process, during the process and after the procedure, namely until the final result is known to ensure that the activities carried out are following what was planned and correct errors occur.

\section{Inhibiting Factors and Countermeasures Related to Parking Management in Garut Kabupaten Regency}

In the management of parking in Garut district, of course, it cannot be separated from the inhibiting factors, including:

a. Awareness

Parking management will later be carried out by HR who are in the Garut Regency Parking Section Transportation Service, and later in terms of carrying out their duties and authorities, if the HR does not have an awareness of their responsibilities, then the task force will not run appropriately according to what has been determined. To increase awareness of these human resources who are in the Department of Transportation, the Parking Section of Garut Regency, that is, they come from their leaders.

b. Communication and coordination

In the implementation of parking management, communication and coordination need to be done and become an essential role in carrying out an activity. This will make their duties and authority better and clearer on their performance. For this reason, good communication is needed as a means of coordination in carrying out their responsibilities and authority. For contact and coordination that occurred in the field until now, it is still not optimal in its implementation. This happens between the Department of Transportation and parking attendants who lack communication related to management problems, causing coordination to be not in line with both.

c. Resources

This unbalanced condition makes the level of supervision of parking management ineffective and the parking attendant supervisors who have not been firm in controlling the parking attendants so that in terms of governance, it becomes less than optimal because there are still parking attendants who are not honest in collecting parking fees. Many parking attendants do not fully wear their official uniforms. The official and unofficial parking attendants are the same when they are on the road doing the parking.

In this study, the efforts made by the Department of Transportation related to parking management are efforts to overcome them. 
a. Doing coaching

Provide guidance to parking attendants and also to parking management staff. The coaching is carried out once a month to maximize their duties and authority further. Because in reality, there are still violations that occurred after the coaching was carried out.

b. Carry out an appeal operation

The appeal was made to the community and also parking attendants in the area. The appeal to the public is to warn them to obey the traffic signs that have been installed, such as signs that are prohibited from parking in that place, because if people use a site where parking is not permitted, it means that the community is using illegal parking or illegal parking which is not allowed by regulations.

c. Maintenance of parking management facilities and infrastructure

In terms of facilities and infrastructure, such as parking lots that are still not adequate, the place is still not enough to be used as a large parking lot so that many vehicles are parked in any area. Also, many are consuming the road, causing congestion along the route.

\section{E. CONCLUSION}

The Garut Regency Parking Section Transportation Office has been carried out or arranged well to implement parking management in the Garut Regency. In planning an activity, it goes well even though there are obstacles faced in parking management. Then the planning carried out in the field is still not optimal. In addition, the organization of the Garut Regency Parking Section Transportation Service is still not optimal because there are still many employees and parking attendants who have not been able to carry out their duties and authorities properly. Meanwhile, based on the mobilization or implementation of the parking management, the Garut Regency Transportation Service must be further improved because, in terms of carrying out their duties and authorities, many parking interpreters violate the regulations that are not following the implementation that has been set. Then the last one is regarding the supervision carried out by the Garut Regency Transportation Service, which is still not optimal even though the best possible maintenance has been carried out with the appeal or guidance given to parties related to parking management in Garut Regency.

In terms of parking management in Garut Regency, it is still not optimal because several factors influence parking management. The first is the awareness factor. The awareness factor is still a problem because the work unit still does not understand the duties and authorities or is still negligent; this affects the community. The second is that the coordination and communication factors are still not balanced and optimal in their implementation in the field. And the third is the resource factor that is still lacking in parking supervisors to supervise parking attendants in the area. For this reason, the Garut Regency UPTD Parking Office has made efforts to overcome parking management problems, namely by guiding employees, appeals and maintenance of parking facilities and infrastructure. However, this has been done, but there are still those who violate the regulations.

\section{REFERENCES}

Arikunto, S. (2005). Manajemen Penelitian. Jakarta: Rineka Cipta.

Badrudin. (2013). Dasar-Dasar Manajemen. Bandung: Alfabeta. 
Fattah, H. N. (2004). Konsep Manajemen Berbasis Sekolah (MBS) Dan Dewan Sekolah. Pustaka Bani Quraisi.

Griffin, R. W. (2004). Manajemen. Jakarta: Erlangga.

Hidayat, A., Munandar, A., \& Armidiana, A. (2018). Implementasi Kebijakan Pengelolaan Parkir Kota Bandung. Publica: Jurnal Pemikiran Administrasi Negara, 10(2), 73-86.

Kesek, F. (2013). Efektivitas dan Kontribusi Penerimaan Pajak Parkir Terhadap Pendapatan Asli Daerah Kota Manado. Jurnal EMBA: Jurnal Riset Ekonomi, Manajemen, Bisnis dan Akuntansi, 1(4).

Maulidya, I., Kurniati, N. L. W. R., \& Andari, T. (2021). Penataan Parkir Di Badan Street of Kota Payakumbuh. Jurnal Penelitian Transportasi Darat, 23(1), 37-54.

Paisal, R. (2014). Implementasi Kebijakan Retribusi Pelayanan Parkir Di Tepi Street of Umum. Jurnal Administrasi Negara, 4(2), 1-15.

Presthus, R. V. (1959). Behaviour and Bureaucracy in Many Cultures. Public Administration Review, 25-35.

Puspitasari, R., \& Mudana, I. K. (2017). Kajian Penataan Parkir di Badan Street of Kota Cirebon. Warta Penelitian Perhubungan, 29(1), 105-122.

Riyanda, R., \& Dompak, T. (2017). Kebijakan Parkir Kota Batam Dalam Peningkatkan Pendapatan Asli Daerah. Jurnal Niara, 10(1).

Soesilowati, E. (2008). Dampak Pertumbuhan Ekonomi Kota Semarang Terhadap Kemacetan Lalulintas di Wilayah Pinggiran dan Kebijakan Yang Ditempuhnya. JEJAK: Jurnal Ekonomi dan Kebijakan, 1(1).

Sugiono. (2016). Metode Penelitian Kuantitatif, Kualitatif, dan R\&D. Bandung: Alfabeta.

Suthanaya, P. A. (2010). Analisis Karakteristik dan Kebutuhan Ruang Parkir pada Pusat Perbelanjaan di Kabupaten Badung. Jurnal Ilmiah Teknik Sipil, 14(1).

Taruno, H. T. (2017). Evaluasi Kebijakan Pengelolaan Parkir Studi Kasus: Kota Semarang. Journal of Governance, 2(2).

Wahyusetyawati, E. (2017). Dilema Pengaturan Transportasi Online. Jurnal RechtsVinding. ISSN, 2089-9009. 